\title{
The tadpole of the Narrow-mouthed Frog Microhyla fissipes from Vietnam (Anura: Microhylidae)
}

\author{
RALF HENDRIX ${ }^{1,2}$, ANNA GAWOR ${ }^{2}$, MIGUEL VENCES ${ }^{3} \&$ THOMAS ZIEGLER ${ }^{2,4}$ \\ ${ }^{1}$ University of Bielefeld, Department of Animal Behaviour, Morgenbreede 45, 33615 Bielefeld \\ ${ }^{2}$ Cologne Zoo, Riehler Straße 173, 50735 Köln, Germany \\ ${ }^{3}$ Division of Evolutionary Biology, Zoological Institute, Technical University of Braunschweig, Spielmannstr. 8, \\ 38106 Braunschweig, Germany \\ ${ }^{4}$ Corresponding author; tziegler@zoo-koeln.de
}

Based on recent mtDNA analyses, Microhyla fissipes Boulenger was removed from the synonymy with $M$. ornata (Duméril \& Bibron) by Matsui et al. (2005), where previously it had been placed by Parker (1934). M. fissipes inhabits southern China (type locality: Taiwan) and large parts of Southeast Asia, including the northern Malay Peninsula (Matsui et al. 2005). As a contribution to future comprehensive revisions of larval morphology of Microhyla Tschudi, we here provide a detailed description of external morphology of reliably identified tadpoles recently collected from the Truong Son mountain range, central Vietnam.

Tadpoles (ZFMK 86752) were collected in a pond within a dried out paddy nearby Phong Nha - Ke Bang National Park (PNKB), Quang Binh Province, Vietnam in August 2006, and deposited in the herpetological collection of the Zoologisches Forschungsmuseum Alexander Koenig (ZFMK), Bonn, Germany. Two adult specimens were collected within PNKB in a semi-deciduous forest of Hang E (ZFMK 86370) and next to a pond in the surroundings of a cassava field in Cha Noi (ZFMK 86426) between June and July 2006. For a specific assignment of the tadpoles, 516 nucleotides of the mitochondrial 16S rRNA gene were seqeunced and compared with homologous fragments of the adult specimens. Sequence congruence was 100\% for all investigated individuals (Genbank accession numbers: EU157074EU157076). Developmental stages are given according to Gosner as reproduced in Altig \& McDiarmid (1999). Morphological terminology follows Altig \& McDiarmid (1999).

Colour in preservative. Body at Gosner stage 41 semitransparent to white, covered with small dark and somewhat stellar-shaped pigments. Dorsal and dorsolateral pigmentation of the body is more dense than ventral. Pigmentation around the nares, the oral disc, and likewise in the range of the intestinal coils of an elevated concentration. Single pigments are situated on the throat and chest. The lower fin and the second half of the upper fin are more or less with dark pigmentation. Pigmentation of the tail forms black stripes along the apex and the ventral side of the myotomes. Dorsal parts of hind limbs with small dark spots.

Description in dorsal view. Body somewhat oval protracted [body width (BW) 0.55 times of body length (BL)] with a rounded snout. The mouth is terminally positioned. Eyes of remarkable size [eye diameter (ED) 0.14 times BL], positioned and directed laterally, bulging, and visible in ventral view [interpupilar distance (IP) 1.07 times BW]. The small round nares are anterodorsally positioned, nearer to the snout than to the pupil [rostro-narial distance (RND) 0.48 times of naro-pupilar distance (NPD)], not developed in early stages. Internarial distance (IND) is 0.15 times IP. Muscles of the tail are widest at the base [width of tail musculature (TMW) at base 0.38 times BW].

Description in lateral view. Body in lateral view slightly round-bellied [body height (BH) 0.90 times BW] with a pointed snout. Distance of the opening of the spiraculum from central point of eye $4.16 \mathrm{~mm}$. The tubular spiraculum is ventromedian positioned at the last third of the body length, oriented in posterior direction and entirely attached to the body. Vent tube completely reduced at this stage. Tail length (TAL) 2.1 times BL and prolonged to a fine pointed filament from the last fourth to the end. Myotomes of the tail musculature are of moderate development and V-shaped [height of tail musculature (TMH) at base 1.09 times TMW at base). Tail musculature is gradually tapering from proximal to its distal end, reaching the tip of the tail. The upper and lower fin of the tail is of remarkable appearance. Upper fin situated behind the base of tail and gradually elevated to the middle. Lower fin at the base and in the middle of the tail higher than the upper fin [height of the lower fin (LF) 1.39 times of the upper fin (UF)]. Forelegs originated behind the gills in the front range of intestinal coils. 
Oral disc. Oral disc terminally positioned, without marginated papillae, labial teeth or hard beaks. The upper lip is slightly extended in the middle and emarginated on both sides which covers the lower lip in resting position. Lower lip U-shaped.

Mean values (in mm) and standard deviations of measurements of the collected tadpoles $(\mathrm{n}=5)$ of $M$. fissipes at Gosner stage 41 are as follows: BH: $3.85 \pm 0.17$; BL: $7.77 \pm 0.55$; BW: $4.28 \pm 0.27$; ED: $1.10 \pm 0.10$; IND: 0.71 \pm 0.07 ; IP: $4.60 \pm 0.22$; LF: $1.00 \pm 0.29$; NPD: $1.27 \pm 0.13$; RND: $1.17 \pm 0.14$; TAL: $14.23 \pm 1.78$; TMH: $1.77 \pm 0.38$; TMW: $1.63 \pm$ 0.16 ; UF: $0.72 \pm 0.10$.

According to Parker (1934), Microhyla fissipes larvae are morphologically very similar to those of M. ornata (sensu stricto). However, Khan (2000) found distinct differences in the buccopharyngeal cavities between tadpoles of $M$. ornata from north-eastern Pakistan, and those from Thailand, such as longer infralabial papillae, more filter rows, and the presence of a postnarial membranous ridge (Matsui et al. 2005). We agree with most of the mentioned authors that future studies are required not only to support the validity of these differences between $M$. ornata (sensu stricto) and $M$. fissipes, but also to examine the taxonomic significance of variations in tadpole morphology reported within continental, and between continental and Taiwanese M. fissipes (see Flower 1899; Liu 1950; Chou \& Lin 1997; Khan 2000; Matsui et al. 2005).
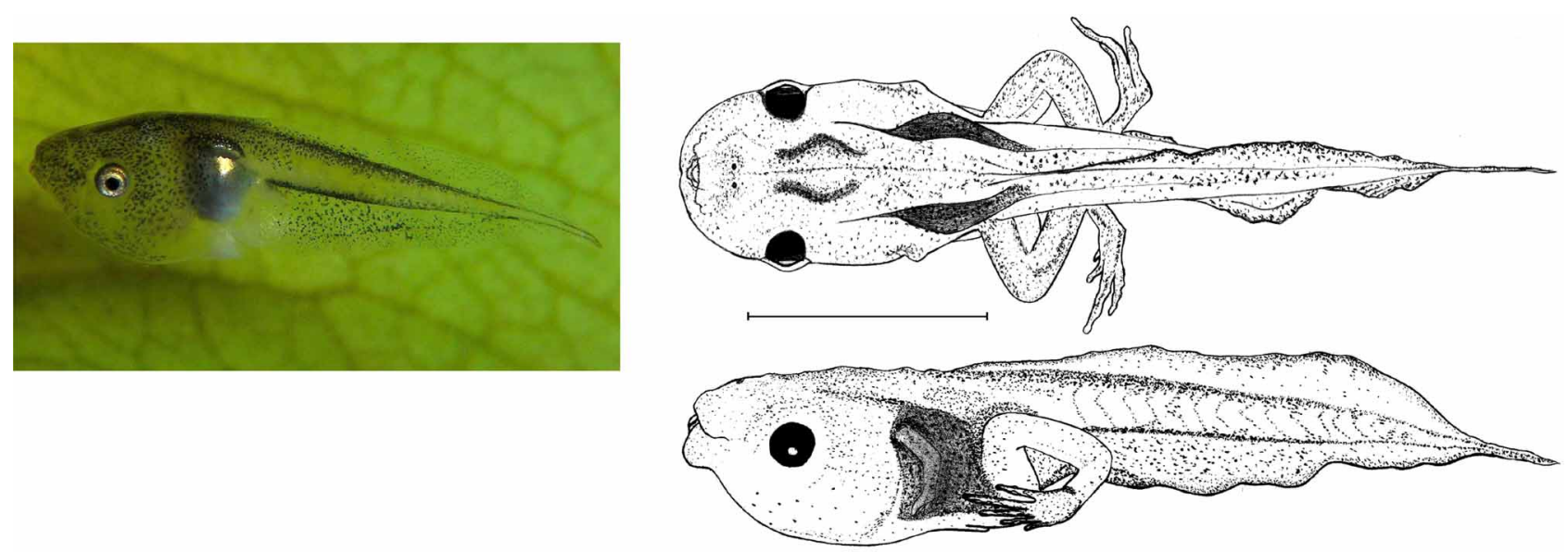

FIGURE 1. Left: Tadpole of Microhyla fissipes from Phong Nha - Ke Bang, Quang Binh Province, Vietnam, in life; right: dorsal and lateral aspects of the preserved tadpole at Gosner stage 41 (scale bar = $5 \mathrm{~mm}$ ). Drawings: Anna Gawor.

We thank the Centre for Natural Resources and Environmental Studies, Vietnam National University, Hanoi, the People's Committee of Quang Binh, the Phong Nha - Ke Bang National Park directorate and the Science Research Centre for their assistance and for issuing respective permits. Current tadpole research in Phong Nha - Ke Bang was funded in large by the Cologne Zoo, the Alexander-Koenig-Gesellschaft (AKG), the Alexander Koenig Stiftung (AKS), the Deutsche Gesellschaft für Herpetologie und Terrarienkunde (DGHT), and by the European Union of Aquarium Curators (E.U.A.C.).

\section{References}

Altig, R. \& McDiarmid, R.W. (1999) Tadpoles: the biology of anuran larvae. The University of Chicago Press, 444 pp.

Chou, W.-H. \& Lin, J.-Y. (1997) Tadpoles of Taiwan. Special Publication of the National Museum of Natural Science, Taichung, 7, 198.

Flower, S.S. (1899) Notes on a second collection of batrachians made in the Malay Peninsula and Siam from November 1896 to September 1898, with a list of the species recorded from these countries. Proceedings of the Zoological Society of London, (1899), $885-916$.

Khan, M.S. (2000) Buccopharyngeal morphology and feeding ecology of Microhyla ornata tadpoles. Asiatic Herpetological Research, 9, 130-138.

Liu, C.C. (1950) Amphibians of western China. Fieldiana Zoolology, 2, 1-400.

Matsui, M., Ito, H., Shimada, T., Ota, H., Saidapur, S. K., Khonsue, W., Tanaka-Ueno, T. \& Wu, G.F. (2005) Taxonomic relationships within the Pan-Oriental Narrow-mouth toad Microhyla ornata as revealed by mtDNA analysis (Amphibia, Anura, Microhylidae). Zoological Science, 22, 489-495.

Parker, H.W. (1934) A monograph of the frogs of the family Microhylidae. London, British Museum (Natural History), vii +208 pp. 